\title{
Model Problem Based Learning Berbantuan Simulasi Komputer Untuk Meningkatkan Penguasaan Konsep Pada Materi Alat-Alat Optik
}

\author{
Khairun Niami*, Kosim, Gunawan \\ Program Studi Pendidikan Fisika, Universitas Mataram \\ *Email: khairunniami40@gmail.com
}

\begin{abstract}
This research aims to determine the increase in mastery of concept through problem based learning model assisted by computer simulations on the material of class XI optical devices in SMAN 8 Mataram. This type of research is quasi-experimental with pretest-posttest control group design. The research population was all students of class XI MIA SMAN 8 Mataram. Sampel taken using purposive sampling technique. Students of class XI MIA 1 were selected as experimental class and class XI MIA 2 as control class. Hypothesis testing using $t$ test with a significance level of 5\% assisted by SPSS 23. Hypothesis testing yielded a significance level of 0.010 for mastery of concepts smaller than 0.05. Based on the provisions, Ho is rejected and it can be concluded that there is an influence of problem based learning models assisted by computer simulations on the mastery of the concepts. This result can be proved by the $\mathrm{N}$-gain test, where there is an increase in mastery of concepts by using a problem based learning model assisted by computer simulations. The highest increase in sub-material for concept mastery data was seen in the reflection devices and lowest sub-material in binocular.
\end{abstract}

Keywords: Problem Based Learning, Computer Simulation, and Mastery of Concept.

\section{PENDAHULUAN}

Pendidikan akan membantu manusia untuk menumbuh kembangkan potensipotensi dan kemampuannya (Tirtarahardja \& Sulo, 2015). Pendidikan tidak terlepas dari peran dan fungsi seorang guru yang merupakan komponen utama dalam dunia pendidikan. Menurut Sanjaya (2013), dalam era informasi sekarang ini telah terjadi perubahan peranan guru. Guru tidak lagi berperan sebagai satu-satunya sumber belajar (learning resources), akan tetapi lebih berperan sebagai pengelola pembelajaran (manager of instruction).

Pembelajaran fisika menekankan pada pemberian pengalaman langsung untuk mengembangkan kompetensi peserta didik. Tetapi, beberapa konsep dalam fisika termasuk dalam konsep abstrak. Adanya beberapa konsep abstrak dalam fisika menyebabkan kesulitan tersendiri dalam penyampaiannya kepada peserta didik. Hal ini kemudian berimplikasi pada rendahnya penguasaan konsep fisika peserta didik (Gunawan et al. 2015). Pemanfaatan teknologi berupa simulasi dan visualisasi merupakan salah satu sarana pembelajaran untuk mendapatkan informasi lebih nyata dari informasi yang bersifat abstrak (Husein et al. 2017).

Hasil observasi di SMAN 8 Mataram, khususnya pada kelas XI MIA pembelajaran fisika masih sangat dominan menempatkan guru sebagai pusat (teacher center). Keadaan tersebut berpengaruh terhadap kurangnya penguasaan konsep peserta didik yang mampu diterapkan dalam kehidupan sehari-hari. Oleh sebab itu, pembelajaran fisika seharusnya disajikan dengan model pembelajaran yang lebih bervariasi serta proses pembelajaran yang berpusat pada peserta didik (student center), sehingga menjadikan peserta didik lebih aktif.

Model pembelajaran yang dapat digunakan sebagai solusi dari permasalahan yang terjadi yaitu, menggunakan Model Problem Based Learning untuk Meningkatkan Penguasaan Konsep pada Materi Alat-Alat Optik. Menurut Aziz et al. 
(2017), model problem based learning merupakan sebuah model pembelajaran yang menyediakan pengalaman autentik yang mendorong peserta didik untuk belajar aktif, mengkonstruksi pengetahuan, dan mengintegrasikan konteks belajar di sekolah dan belajar di kehidupan nyata secara alamiah sebagai rangkaian aktivitas pembelajaran yang menekankan pada proses penyelesaian masalah secara ilmiah. Sedangkan menurut Kosasih (2014) bahwa, model PBL merupakan suatu metode pembelajaran yang menantang peserta didik untuk "belajar bagaimanan belajar", bekerja secara berkelompok untuk mencari solusi dari permasalahan dunia nyata. Berdasarkan beberapa pendapat diatas, peneliti menyimpulkan bahwa model problem based learning merupakan model pembelajaran yang menekankan penyajian masalah sebagai titik tolak untuk memperoleh pengetahuan baru dengan mencari solusi secara kolaboratif.

Adanya beberapa konsep fisika yang abstrak juga sering kali menjadi kendala bagi guru dalam menyampaikan materi kepada peserta didik, sehingga peserta didik belum optimal dalam memahami konsep yang dijelaskan guru, maka peneliti menggunakan media simulasi komputer, yang bertujuan memberikan pengalaman belajar yang lebih konkret melalaui penciptaan tiruan-tiruan bentuk yang mendekati suasana sebenarnya. Simulasi komputer yang digunakan dalam penelitian ini terdiri dari tujuh buah simulasi. Simulasi tersebut dapat dijalankan menggunakan aplikasi Macromedia Flash. Tujuah buah animasi tersebut digunakan untuk menyampaikan materi alat-alat optik selama empat kali pertemuan.

Penguasaan konsep adalah kemampuan peserta didik untuk memahami konsep-konsep suatu materi pembelajaran baik secara teori maupun penerapannya dalam kehidupan sehari-hari (Arianti et al.
2016). Sedangkan menurut Silaban (2014) penguasaan konsep sebagai usaha yang harus dilakukan peserta didik dalam merekam dan mentransfer kembali sejumlah informasi dari suatu materi pelajaran tertentu yang dapat dipergunakan dalam memecahkan masalah, menganalisis, menginterpetasikan pada suatu kejadian tertentu. Berdasarkan beberapa pendapat tersebut dapat disimpulkan, bahwa penguasaan konsep dapat mempengaruhi kemampuan peserta didik dalam memecahkan berbagai masalah, baik yang terkait dengan konsep itu sendiri maupun penerapannya dalam situasi baru. Konsep dapat menunjukkan hubungan suatu konsep dengan konsep lain yang lebih sederhana sebagai dasar perkiraan atau jawaban. Konsep diperoleh dari fakta, peristiwa, pengalaman melalui generalisasi dan berpikir abstrak, kegunaan konsep untuk menjelaskan dan meramalkan. Indicator penguasaan konsep menurut taksonomi Bloom yang disempurnakan oleh Anderson dan Krathwohl (2015) dibagi menjadi enam jenjang mulai dari jenjang yang paling rendah ke jenjang yang paling tinggi, yaitu mengingat, memahami, mengaplikasikan, menganalisis, mengevaluasi, dan mencipta (remember, understand, apply, analyze, evaluate, and create) (dalam Widoyoko, 2016).

\section{METODE PENELITIAN}

Penelitian ini merupakan penelitian kuasi eksperimen dengan menggunakan desain penelitian, yaitu non-equivalent control grup design. Proses pembelajaran menggunakan model pembelajaran problem based learning yang dipadukan media simulasi komputer pada kelas eksperimen dan model pembelajaran direct instruction pada kelas kontrol. Instrumen penguasaan konsep menggunakan tes pilihan ganda dengan subjek penelitian adalah peserta 
didik kelas XI MIA di SMAN 7 Mataram Tahun Ajaran 2017/2018.

Data hasil penguasaan konsep di uji prasyarat, berupa uji homogenitas menggunakan uji-F dan uji normalitas menggunakan uji Chi Kuadrat. Kemudian dilanjutkan dengan uji hipotesis menggunakan uji-t polled varian. Sedangkan untuk mengetahui peningkatan per sub materi digunakan uji $n$-gain

\section{HASIL DAN PEMBAHASAN}

Data penelitian yang dikumpulkan dalam penelitian ini disesuaikan dengan keperluan analisis, yakni analisis penguasaan konsep peserta didik pada materi alat-alat optik yang diajarkan menggunakan model problem based learning berbantuan simulasi komputer pada kelas ekeperimen dan model direct instruction pada kelas kontrol. Berikut akan dipaparkan hasil penelitian pengaruh model problem based learning berbantuan simulasi komputer untuk meningkatkan penguasaan konsep pada materi alat-alat optik.

Hasil penelitian yang sudah dilakukan menggambarkan kemampuan awal penguasaan konsep peserta didik baik kelas eksperimen maupun kelas kontrol berdasarkan tes awal masih rendah. Hal ini terlihat dari rata-rata tes penguasaan konsep masing-masing kelas. Nilai rata-rata tes awal yang rendah dikarenakan peserta didik belum diberikan perlakuan. Selain itu, nilai rata-rata tes awal yang rendah disebabkan karena kedua kelas belum memperoleh materi alat-alat optik sesuai dengan jenjangnya. Pengetahuan yang mereka miliki hanya berupa pengetahuan yang sederhana tentang alat-alat optik yang mereka peroleh di sekolah menengah pertama.

Data hasil tes awal penguasaan konsep dianalisis menggunakan uji-F untuk mengetahui homogenitas peserta didik terhadap materi alat-alat optik. Hal tersebut dilakukan karena pada tes awal peneliti ingin melihat penyebaran data kedua kelas atau kemampuan awal kedua kelas sebelum diberi perlakuan. Setelah melakukan tes awal, maka peneliti memberikan perlakuan yang berbeda pada kedua kelas. Untuk mengukur pengaruh perlakuan yang telah diberikan, kedua kelas diberikan tes akhir dengan materi, jumlah, dan bobot soal yang sama dengan soal tes awal. Berdasarkan nilai dan analisis data tes akhir, kelas eksperimen memperoleh nilai rata-rata tes akhir lebih tinggi dibandingkan dengan kelas kontrol yaitu 63,29 untuk kelas eksperimen dan 52,15 untuk kelas kontrol. Peningkatan ratarata penguasaan konsep fisika peserta didik pada kelas eksperimen dan dan kontrol disajikan pada Gambar 1.

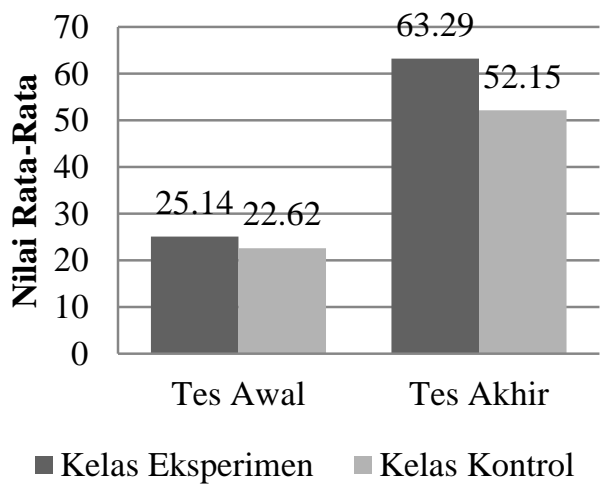

Gambar 1 Perbandingan Nilai Rata-Rata Penguasaan Konsep.

Secara sekilas dalam Gambar 1 sudah dapat dilihat bahwa model problem based learning memberikan pengaruh yang lebih baik bila dibandingkan dengan pembelajaran konvensional atau dapat dikatakan peningkatan nilai rata-rata merupakan pengaruh dari perlakuan yang diberikan pada kelas eksperimen dan kelas kontrol.

Untuk membuktikan lebih jauh secara statistik maka dilakukan uji homogenitas serta uji normalitas tes akhir dan didapatkan kedua kelas homogen dan terdistribusi normal. Selanjutnya dilakukan uji hipotesis menggunakan teknik uji-t polled varian. Berdasarkan hasil 
perhitungan menggunakn uji-t polled varian berbantuan SPSS 23 diperoleh Sig. (2-tailed) 0,01 ; angka ini jauh dibawah nilai signifikansi yang ditetapkan yaitu 0,05. Jadi, dapat disimpulkan bahwa model problem based learning berbantuan simulasi komputer berpengaruh signifikan terhadap penguasaan konsep peserta didik.

Penguasaan konsep dapat meningkat melalui model problem based leaarning berbantuan simulasi komputer karena peserta didik dihadapkan langsung pada masalah, sehingga mendorong peserta didik untuk belajar aktif atau mandiri, membangun pengetahuan baru, dengan saling bertukar pikiran dengan teman kelompok dan saling membantu dalam menyelesaikan tugas atau LKPD yang disertai bantuan simulaisi komputer yang berfungsi untuk memvisualisasikan konsepkonsep abstrak pada materi alat-alat optik. Dengan terlibat secara langsung dalam memecahkan masalah selama proses pembelajaran maka peserta didik dapat sebelumnya mengenai model problem based learning, yaitu menurut Hastuti et al. (2016), menyatakan bahwa model problem based learning berbantuan media virtual berpengaruh terhadap penguasaan konsep fisika peserta didik. Lebih lanjut menurut Dewi et al. (2016), menyatakan bahwa terdapat pengaruh penguasaan konsep fisika peserta didik kelas eksperimen yang diberikan model pembelajaran berbasis masalah berbantuan simulasi virtual.

Peningkatan penguasaan konsep fisika dapat dilihat dari hasil uji $\mathrm{N}$-gain secara keseluruhan dan per sub materi. Hasil uji N-gain pada kelas eksperimen menunjukkan nilai yang lebih tinggi dibandingkan kelas kontrol secara keseluruhan. Hal ini sejalan dengan pendapat Nardin et al. (2016), menyatakan penguasaan konsep fisika yang diajar dengan model pembelajaran berbasis masalah berada pada kategori yang tinggi. Adapun nilai $\mathrm{N}$-gain kelas eksperimen dan kelas kontrol pada tiap sub materi disajikan

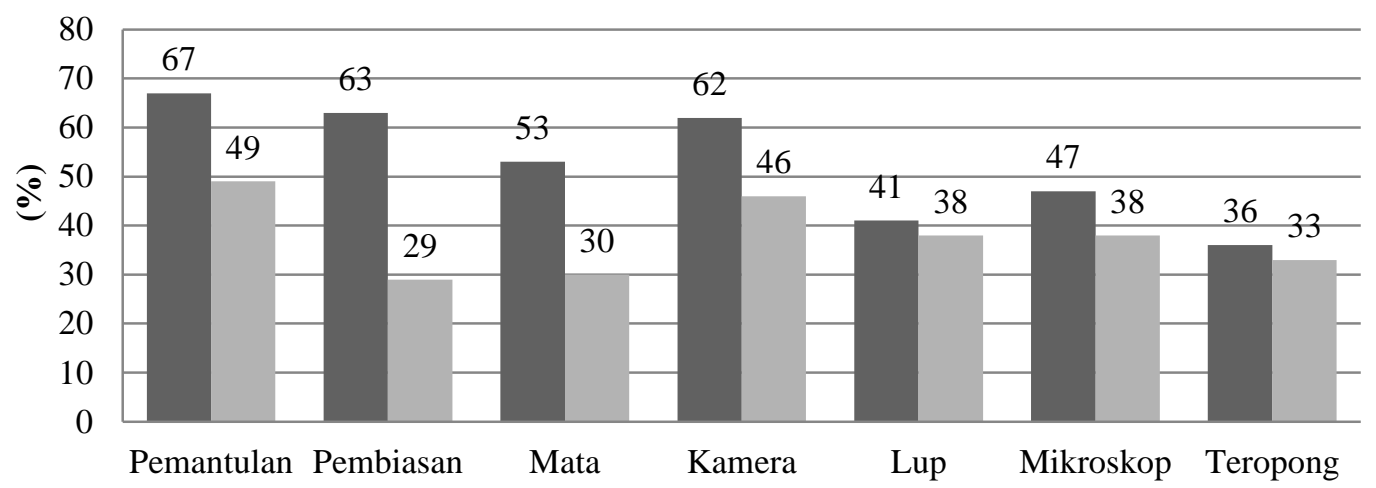

Sub Materi

- Kelas Eksperimen $\quad$ Kelas Kontrol

menguasai konsep dengan baik. Hal ini juga pada Gambar 2.

diperkuat dengan hasil penelitian

Gambar 2. Perbandingan Nilai N-gain Per Sub Materi

Berdasarkan Gambar 2, terlihat persentase peningkatan lebih baik terjadi pada kelas eksperimen untuk setiap sub materi. Peningkatan tersebut dikarenakan, adanya perbedaan perlakuan, dimana pada kelas eksperimen peserta didik membangun konsepnya secara sendiri dari permasalahan yang diberikan guru, serta dengan adanya penggunaan simulasi komputer materi alatalat optik yang sulit untuk divisualisasikan dapat disampaikan secara mudah dan menarik. Peningkatan tertinggi, yaitu pada 
sub materi pemantulan yang dikarenakan materi tersebut adalah materi awal yang masih sederhana dan sudah didapatkan pula pada jenjang sekolah menengah pertama, sehingga dengan adanya bantuan simulasi komputer juga peserta didik lebih menguasai lagi sub materi tersebut.

\section{PENUTUP}

Berdasarkan hasil penelitian, analisis data dan pembahasan, maka dapat diambil kesimpulan, model problem based learning berbantuan simulasi komputer dapat meningkatkan penguasaan konsep peserta didik pada materi alat-alat optik, Uji N-gain yang dilakukan didapatkan bahwa baik kelas eksperimen maupun kelas kontrol samasama mengalami peningkatan pada penguasaan konsep tetapi peningkatan tertinggi terjadi pada kelas eksperimen baik uji $\mathrm{N}$-gain per sub materi.

Adapun saran yang diberikan peneliti yaitu, model problem based learning berbantuan simulasi komputer dapat dijadikan alternatif strategi pembelajaran yang dapat diterapkan. Namun, dalam penerapannya memerlukan perencanaan dan persiapan yang matang sebelum diterapkan dikelas agar proses pembelajaran dapat berjalan sesuai dengan tujuan pembelajaran yang hendak dicapai.

\section{REFERENSI}

Arianti, B. I., Sahidu, H., Harjono, A., dan Gunawan, G., 2016. Pengaruh Model Direct Instruction Berbantuan Simulasi Virtual terhadap Penguasaan Konsep Siswa. Jurnal Pendidikan Fisika dan Teknologi. 4(2): 159-163.

Aziz, A., Rokhmat, J. \& Kosim, K. 2017. Pengaruh Model Pembelajaran Berbasis Masalah dengan Metode Eksperimen terhadap Hasil Belajar Fisika Siswa Kelas X SMAN 1 Gunungsari Kabupaten Lombok
Barat Tahun Pelajaran 2014/2015. Jurnal Pendidikan Fisika dan Teknologi, 1(3), 200-204

Dewi, S. M., Harjono, A., \& Gunawan. 2016. Pengaruuh Model Pembelajaran Berbasis Masalah Berbantuan Simulasi Komputer terhadap Penguasaan Konsep dan Kreativitas Fisika Siswa SMAN 2 Mataram. Jurnal Pendidikan Fisika dan Teknologi, 2(3), 123-128.

Gunawan, Harjono, H., \& Sahidu, H. 2015. Studi Pendahuluan pada Upaya Pengembangan Laboraturium Virtual Bagi Calon Guru Fisika. Jurnal Pendidikan Fisika dan Teknologi, I(2), 140-145.

Hastuti, A., Syahidu, H., \& Gunawan. 2016. Pengaruh Model PBL Berbantuan Media Virtual terhadap Kemampuan Pemecahan Masalah Fisika. Jurnal Pendidikan Fisika dan Teknologi, 2(3), 129-135.

Husein, S., Herayanti, L., \& Gunawan, G. 2017. Pengaruh Penggunaan Multimedia Interaktif Terhadap Penguasaan Konsep dan Keterampilan Berpikir Kritis Siswa pada Materi Suhu dan Kalor. Jurnal Pendidikan Fisika dan Teknologi, 1(3), 221-225.

Kosasih, E. 2014. Strategi Belajar dan Pembelajaran Implementasi Kurikulum 2013. Bandung: Yrama Widya.

Nardin, Muris, \& Tawil, M. 2016. Pengaruh Model Pembelajaran Berbasis Masalah terhadap Minat Belajar dan Penguasaan Konsep Fisika pada Peserta Didik Kelas VII SMP Negeri 26 Makasar. Jurnal Sains dan Pendidikan Fisika, 12(2), 117127.

Sanjaya, H. W. 2013. Perencanaan dan Desain Sistem Pembelajaran. Jakarta: Kencana.

Silaban, B. 2014. Hubungan Antara Penguasaan Konsep Fisika dan Kreativitas dengan Kemampuan 
Memecahkan Masalah pada Materi

Pokok Listrik Statis. Jurnal

Penelitian Bidang Pendidikan, 20(1), 65-75.

Tirtarahardja, U \& Sulo, S.L. 2015. Pengantar Pendidikan. Jakarta: PT Rineka Cipta.

Widoyoko, P. E. S. 2016. Hasil Pembelajaran di Sekolah. Yokyakarta: Pustaka Belajar. 